\title{
Paternity analysis of Populus nigra L. offspring in a Belgian plantation of native and exotic poplars
}

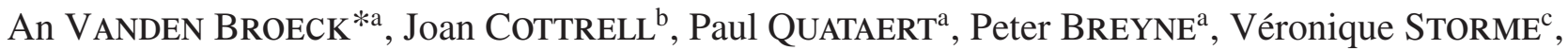 \\ Wout BOERJAN $^{\mathrm{c}}$, Jos VAN SLYCKEN ${ }^{\mathrm{a}}$
${ }^{a}$ Institute for Forestry and Game Management (IBW), Research Station of the Flemish Community, Gaverstraat 4, Geraardsbergen, 9500 , Belgium
${ }^{\mathrm{b}}$ Forest Research, Northern Research Station, Roslin, Midlothian, Scotland EH25 9SY, UK
${ }^{\mathrm{c}}$ Department of Plant Systems Biology Flanders Interuniversity Institute for Biotechnology (VIB) Ghent University, K.L. Ledeganckstraat 35, \\ Ghent, 9000, Belgium
}

(Received 13 June 2005; accepted 6 January 2006)

\begin{abstract}
Gene flow from cultivated poplar plantations into wild populations of Populus nigra L. is considered to represent a potential threat to the survival of $P$. nigra. In this study we investigated if pollen competition of Populus nigra L. and Populus $\times$ canadensis Moench in fertilising $P$. nigra ovules detected in a greenhouse experiment also occurs under field conditions. The results confirm non-random mating between males of $P$. $\times$ canadensis and P. nigra in fertilizing P. nigra females in the artificial species-mixed Belgian poplar stand. A paternity analysis also revealed non-random intra-specific mating patterns within $P$. nigra in the stand. No paternities were assigned to the male cultivar $P$. nigra cv. Italica. Practical implications for the conservation of wild P. nigra populations are discussed.
\end{abstract}

Populus / intra- and inter-specific crossing / introgression / conservation / paternity analysis

Résumé - Analyse de paternité dans des descendances de Populus nigra L. issues d'une plantation belge de peupliers indigènes et exotiques. Les flux de gènes à partir des plantations de peupliers cultivés vers les populations sauvages de Populus nigra L. peut représenter une menace potentielle pour la survie de P. nigra. Dans cette étude, nous avons voulu vérifier si la compétition pollinique entre pollen de $P$. nigra et de $P$. $\times$ canadensis Moench. observée en croisements artificiels sur $P$. nigra se produit également au sein d'une plantation in situ. Les résultats de cette étude confirment qu'une fertilisation non aléatoire entre les parents mâles de $P$. $\times$ canadensis et $P$. nigra d'une part et les parents femelles de $P$. nigra d'autre part a bien lieu sur le terrain. Une analyse de paternité indique également la présence d'une fertilisation intraspécifique non aléatoire au sein des $P$. nigra. Aucun lien de paternité n'a pu être attribué au cultivar mâle $P$. nigra cv. Italica. Les implications pratiques pour la conservation de populations sauvages de $P$. nigra sont discutées.

Populus / croisement intra- et interspecifique / introgression / conservation / analyse de paternité

\section{INTRODUCTION}

Gene flow from cultivated poplar plantations into wild European black poplar (Populus nigra L.) populations (i.e. introgression) may represent a potential threat for black poplar $[4,9,11,18,30]$. In view of the fact that habitat reduction followed by introgressive hybridisation can lead to the extinction of rare plant species, native poplars are believed to be the most threatened forest tree species of old, natural floodplain forests in the temperate zones [18]. Not only introgression of genes from exotic species (mainly Populus deltoides Bart. ex-Marsh. and $P$. trichocarpa Torr. Ex Gray) via genetically narrow based hybrid cultivars constitutes a potential threat but also from non-hybrid $P$. nigra cultivars like the Lombardy poplar (P. nigra cv. Italica). This cultivar is present as large numbers of individuals with identical genotype which may, under certain circumstances, swamp the gene pool of native black poplar, thereby reducing genetic diversity of the native poplars [4].

\footnotetext{
*Corresponding author: An.vandenbroeck@inbo.be
}

Recently in Belgium, evidence was found for introgression of genes of $P$. deltoides in the offspring of an open pollinated (OP) P. nigra female [30]. This was the first study to present evidence for introgression of foreign genes into OP offspring of a wild P. nigra tree. In addition, it was shown that crosses between $P$. nigra females and $P . \times$ canadensis males are compatible and can produce viable seeds under field conditions [31]. However, most studies that have investigated the genetic origin of open pollinated offspring of $P$. nigra detected no introgression of foreign genes. This is true even in those circumstances in which flowering males of $P . \times$ canadensis Moench (syn. $P . \times$ euramericana (Dode) Guinier, cross between $P$. deltoides and $P$. nigra) were present in the vicinity $[2,9,14,22,26]$. These contrasting results might be explained, at least partly, by the influence of competition between pollen of different sources. Pollen competition is understood here as all processes involved in the ability of pollen to fertilise a finite number of ovules and to produce viable seeds. Artificial controlled crosses in greenhouse conditions confirmed that 
non-random mating occurs when pollen mixtures containing $P$. nigra and $P . \times$ canadensis pollen are applied to female $P$. nigra flowers [31]. In a mixed pollen cloud applied in a controlled cross, pollen of $P$. nigra was more successful than that of $P$. $\times$ canadensis in pollinating female black poplars $[3,26,31]$. However, it is generally assumed that greenhouse conditions can differ significantly from field conditions. Field populations are likely to experience smaller and more variable pollen load sizes than those used in greenhouse experiments [19].

In this study, we investigate whether non-random mating occurs under field conditions in an artificial species-mixed poplar stand located in Belgium when the pollen cloud around $P$. nigra ovules contains pollen from both $P$. nigra and $P$. $\times$ canadensis trees. This study differs from former studies (e.g. $[2,7,9,14,22,26])$ in that a higher number of $P . \times$ canadensis males surround the $P$. nigra females investigated. Furthermore, we combined a greater number of diagnostic molecular markers than in former studies thereby increasing the probability of being able to detect mating events of $P$. nigra females and $P . \times$ canadensis males. The SSR marker WPMS09 [7], the isozyme systems LAP, PGM, PGI [24] and the nuclear codominant STS marker win3 [9] were found to be diagnostic in discriminating between parent $P$. nigra, $P$. deltoides and the F1 hybrid, $P . \times$ canadensis. While it is possible to differentiate between first generation hybrid and non-hybrids using any one of these markers, further generations of hybrids and B1-hybrids from backcrossing cannot always be accurately assigned using a single marker [10]. However, it is possible to increase the probability of detecting hybrids from backcrossing by combining the data from different enzyme and/or nuclear markers.

Besides the inter-specific mating events between black poplar females and hybrid males, we also investigated intraspecific mating events of black poplar based on microsatellite markers (SSRs). Paternity analysis based on SSRs has been used successfully in the study of intra-specific and interspecific mating patterns in Populus $[17,26]$. To our knowledge, this is the first study to present data for intra-specific pollen gene flow in a P. nigra stand.

The main objectives of this study were: (i) to quantify the frequency of mating events of $P$. nigra females with $P$. $\times$ canadensis hybrids, and (ii) to assess intra-specific mating events of black poplar in the artificial species-mixed poplar stand on an individual clone and tree basis. Furthermore, we investigated whether gene flow occurred between the widely planted male cultivar $P$. nigra cv. Italica growing outside the stand and the $P$. nigra females inside the stand.

\section{MATERIAL AND METHODS}

\subsection{Study site}

The study site consists of an artificial stand of native and exotic poplars located at Marcq (Edingen), $50^{\circ} 40^{\prime} 30^{\prime \prime} \mathrm{N} / 4^{\circ} 00^{\prime} 00^{\prime \prime}$ E, $30 \mathrm{~km}$ Southwest of Brussels (Belgium) and composed of 11, 56 (including 14 flowering male) and 19 (including 14 flowering male) trees of $P$. deltoides, $P$. nigra and $P$. $\times$ canadensis, respectively (Fig. 1). The study stand covers an area of 0.4 ha $(200 \mathrm{~m} \times 20 \mathrm{~m})$ and is located at the edge of a large poplar plantation covering a total area of 5.25 ha. This large plantation is composed of clones of $P$. deltoides, $P$. trichocarpa, $P . \times$ canadensis, $P . \times$ generosa, $P$. deltoides $\times$ P. maximowiczii, P. trichocarpa $\times$ P. lasiocarpa and P. trichocarpa $\times$ $P$. yunanensis. A more detailed description of the study site and the plant material is given in Vanden Broeck et al. [29]. A row plantation of mature trees of $P$. nigra cv. Italica is located outside the study stand at a distance of about $500 \mathrm{~m}$ to the North. The study plot is situated in an agricultural landscape in which there are many poplar plantations of $P . \times$ canadensis but no stands of $P$. nigra (except plantations of $P$. nigra cv. Italica). The nearest known $P$. nigra stand (except $P$. nigra cv. Italica) is an artificial stand located $20 \mathrm{~km}$ away.

\subsection{Plant material}

In 1999, seeds were collected in the study stand from the lower branches on the southern side of the crown of two open pollinated (OP) black poplar females named N01a and N04. N01a is a ramet collected from an autochthonous tree and N04 is a ramet collected from a black poplar growing in Hungary. In 2000, seeds were collected again from the same tree NO1a, from another ramet of the same genet N01b and from a third female N01' which was a different genet. In total 5 OP progenies ( 2 in 1999 and 3 in 2000) from three different genets (N01, N01', N04) were harvested (Tab. I). The relative positions of the mother trees are given in Figure 1. Seeds were extracted from the catkins and surface sown in trays in the greenhouse on substrate (50\% white peat $/ 50 \%$ black peat) within $24 \mathrm{~h}$ of collection. From each progeny, young leaves were harvested from 30 to 35 seedlings selected at random (Tab. I). A proportion of these leaves was used within $24 \mathrm{~h}$ for isozyme analysis, while the remainder was lyophilised prior to DNA-extraction. DNA-extraction was carried out using the DNeasy Plant Miniprep Kit (Qiagen, Helden, Germany). Leaves were also collected for DNA-extraction and paternity analysis from each male black poplar tree, two black poplar trees of undetermined sex (M102 and M103) (Fig. 1), and P. nigra cv. Italica.

In order to have some indication of the relative crown volumes of the $P$. nigra males, stem diameter, which is related to crown volume [8] was measured at breast height for all the candidate fathers of $P$. nigra in the poplar plantation.

\subsection{Identification of hybrids}

Morphological observations were used for a first screening of putative hybrids with hybrid and non-hybrid seedlings from controlled crosses as standards. Visual observations of the leaf morphology of the 1-year old seedlings were performed. Other characters, including the general shape of the leaf, the angle between the midrib and the first lower lateral vein [16], the growth habit and the stem form (circular/rectangular) [12] were also assessed in this first screening. Seedlings from the following controlled crosses were used as standards: $P$. nigra $\times P$. nigra, $P$. deltoides $\times P$. nigra, $P$. nigra $\times P . \times$ canadensis and $P$. trichocarpa $\times$ P. trichocarpa.

The molecular analysis included five diagnostic markers that had proved to be useful for the detection of $P$. deltoides-specific alleles in hybrids with P. nigra [24]; three diagnostic enzyme systems [24], the SSR locus WPMS09 [24] and the nuclear STS marker win3 [9]. The analysis of the diagnostic enzyme systems PGI, PGM and LAP, and of the nuclear STS marker win3 was performed as described by Fady 


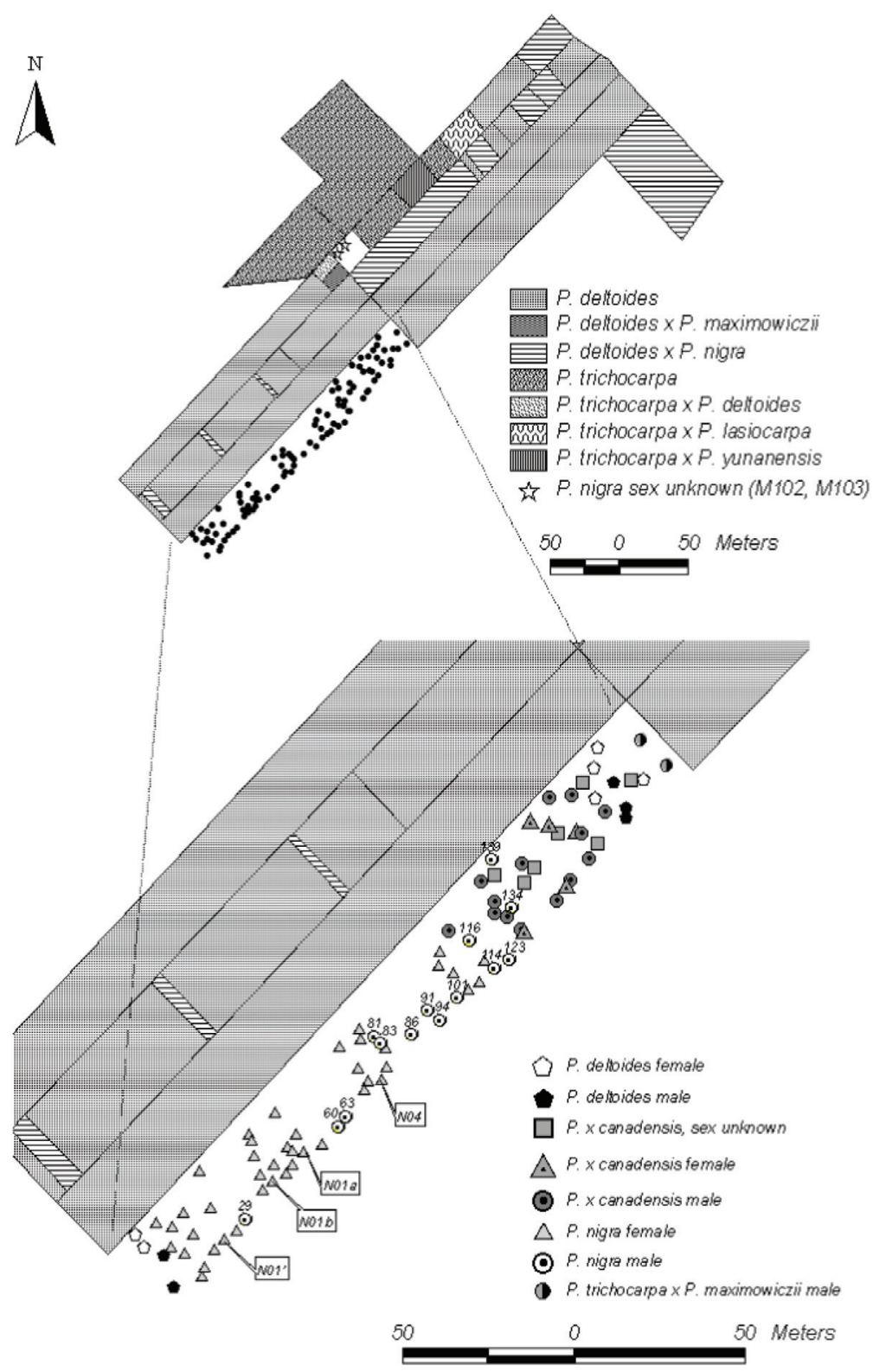

Figure 1. Location and species composition of the study site in the poplar plantation 'Marcq'. The location of the four $P$. nigra mother trees N01a, N01b, N01' and N04 sampled are labelled, the male black poplar trees are indicated by a number.

and Hochu [6] and Heinze [9], respectively. The analysis of the SSR locus WPMS09 is described below. Based on the combined molecular marker data the level of introgression of genes from $P$. deltoides in the offspring of $P$. nigra was estimated. The following reference samples were included in the molecular analysis: P. nigra cv. Wolterson, $P$. deltoides cvs. Harvard, Peoria and $P . \times$ canadensis cvs. Gaver, Ghoy, Robusta.

\subsection{Intra-specific mating patterns}

Intra-specific mating patterns were studied by conducting a paternity analysis on the 5 OP progenies. Samples of the 5 OP progenies (155 seedlings, Tab. I) and of all candidate father trees of P. nigra lo- cated in the total poplar plantation (14 P. nigra males from the study stand $+2 P$. nigra trees with unknown sex located in the total plantation) were analysed using 14 SSR loci (Tab. II). Furthermore, $P$. nigra cv. Italica, located outside the poplar plantation was also included as a candidate father and was analysed for 5 SSR loci; PMGC14, WPMS09, WPMS14, WPMS16 and WPMS20 (Tab. II). Primer sequences and PCR-profiles were as described by van der Schoot et al. [27] and Smulders et al. [25]. Seven SSR loci used in this study have been mapped by Cervera et al. [5] (Tab. II) and can be considered to be unlinked on the basis of their map position. Fragment analyses were performed on an ABI 310 Prism Genetic Analyser (Perkin Elmer - Applied Biosystems, Forster City, CA). The software programs Genescan and Genotyper 2.5 (PE - Applied Biosystems) were used to process and score the SSR data. 
Table I. Number of seeds used for paternity analyses.

\begin{tabular}{lcccc}
\hline $\begin{array}{l}\text { Collection } \\
\text { year }\end{array}$ & $\begin{array}{l}\text { Code } \\
\text { genet }\end{array}$ & Ramet ID & $\begin{array}{c}\text { Progeny } \\
\text { label }\end{array}$ & No. seeds analysed \\
\hline 1999 & N01 & N01a & N1a99 & 30 \\
& N04 & N04 & N04 & 35 \\
\hline 2000 & N01 & N01a & N01a00 & 30 \\
& N01 & N01b & N01b & 30 \\
& N01 & N01' & N01 & 30 \\
\hline TOTAL & & & & 155 \\
\hline
\end{tabular}

Table II. SSR loci used for paternity analysis.

\begin{tabular}{lcc}
\hline Locus & Repeat motif, & $\begin{array}{c}\text { Linkage } \\
\text { group }^{\mathrm{d}}\end{array}$ \\
\hline PMGC14 $^{\mathrm{a}}$ & $\mathrm{CTT}$ & XIII \\
WPMS03 $^{\mathrm{b}}$ & $(\mathrm{GT})_{26-1}$ & - \\
WPMS04 $^{\mathrm{b}}$ & $(\mathrm{GT})_{25}$ & - \\
WPMS05 $^{\mathrm{b}}$ & $(\mathrm{GT})_{27}$ & XII \\
WPMS09 $^{\mathrm{b}}$ & $(\mathrm{GT})_{21}(\mathrm{GA})_{24}$ & VI \\
WPMS10 $^{\mathrm{b}}$ & $(\mathrm{GT})_{23}$ & III \\
WPMS12 $^{\mathrm{c}}$ & $(\mathrm{GT})_{19}$ & VI \\
WPMS13 $^{\mathrm{c}}$ & $(\mathrm{GT})_{22}$ & VIII \\
WPMS14 $^{\mathrm{c}}$ & $(\mathrm{CGT})_{28-3}$ & - \\
WPMS15 $^{\mathrm{c}}$ & $(\mathrm{CCT})_{14-3}$ & - \\
WPMS16 $^{\mathrm{c}}$ & $(\mathrm{GTC})_{8}(\mathrm{ATCCTC})_{5}$ & VII \\
WPMS18 $^{\mathrm{c}}$ & $(\mathrm{GTC})_{13}$ & - \\
WPMS19 $^{\mathrm{c}}$ & $(\mathrm{CAG})_{28-3}$ & - \\
WPMS20 $^{\mathrm{c}}$ & $(\mathrm{TTCTGG})_{8}$ & - \\
\hline
\end{tabular}

-: Not mapped due to absence of polymorphism in the mapping population. ${ }^{a}$ From Poplar Molecular Genetics Cooperative (http://www.ornl.gov/sci/ipgc); ${ }^{\mathrm{b}}$ from van der Schoot et al. (2000); ${ }^{\mathrm{c}}$ from Smulders et al. (2001); ${ }^{\mathrm{d}}$ mapped by Cervera et al. (2001).

In order to characterize the SSR loci, expected heterozygosity $(\mathrm{He})$ and number of alleles $(\mathrm{N})$ were calculated at the progeny level (total offspring) and at the parental level (adult black poplars in the stand) using the software POPGENE 3.31 (http://www.ualberta.ca/ fyeh/index.htm).

Paternity analysis was carried out using a likelihood-based approach and the program CERVUS 2.0 [20]. Taking into account that no other indigenous black poplar trees or black poplar plantations were found within a distance of $20 \mathrm{~km}$ from the poplar plantation 'Marcq' (except plantations of the male cultivar P. nigra cv. Italica), we assumed that the majority of the potential fathers $(85 \%)$ were sampled. A $1 \%$ error rate (genotyping errors, mutations and null alleles) [20] was also assumed. The analysis is based on paternity assigned at $95 \%$ and $80 \%$ statistical confidence levels (C.L.) and 10000 simulated offspring [20]. Identical SSR genotypes of potential males were treated as one potential father in the paternity analysis. Repeated mother-offspring mismatches and estimated null allele frequencies calculated by CERVUS 2.0 were used to detect null alleles. Based on the results of the paternity analysis, the contribution of each male clone as a pollen donor was evaluated by using $\chi$-square tests of goodness-of-fit against the null hypothesis of random mating.

\section{RESULTS}

\subsection{Identification of hybrids}

No typical morphological leaf or seedling characteristics of $P$. $\times$ canadensis (or of P. nigra $\times$ P. trichocarpa) hybrids were found in the total $P$. nigra offspring analysed. The molecular analysis confirmed the morphological observations. Based on the combined dataset of the three isozymes and two DNA markers (WPMS09 and win3), no genes of P. deltoides were detected in the total offspring analysed. Isozyme analysis of the 5 progenies resulted in a clear banding pattern characteristic of $P$. nigra for all seedlings analysed (155/155). No specific alleles of $P$. deltoides were detected at any of the three isozyme loci investigated (pgi-2, pgm-2, lap-1). Analysis of the locus win 3 resulted in a clear banding pattern for 151/155 seedlings investigated. Data for $4 / 155$ seedlings are lacking due to death of seedlings. For all the seedlings that were analysed successfully, the amplification products consisted of one band at approx. 150-180 bp. According to Heinze [9], this banding pattern can be considered to be specific for P. nigra. The amplification products consisted of one band at approximately $260 \mathrm{bp}$ for all the reference samples of $P$. deltoides and a combination of the two bands (150-180 bp and $260 \mathrm{bp}$ ) for the references of $P . \times$ canadensis. For the diagnostic SSR marker WPMS09 [7], the allele of $234 \mathrm{bp}$ that is specific for $P$. deltoides, was absent in the total progeny as well as in the adult P. nigra trees sampled.

\subsection{Intra-specific mating patterns}

Table III summarises the genetic analysis based on the 14 SSR loci for the 19 P. nigra adults ( 3 sampled females + 14 males from the study stand $+2 P$. nigra trees of unknown sex located in the total plantation) and the total offspring (5 progenies). The observed variability at the 14 loci was rather small with the number of alleles per locus ranging from 4 to 11 and a total number of 97 and 89 alleles for the adults and the total offspring, respectively (Tab. III). The average number of alleles was similar in the parent generation $(N=6.9)$ and the total offspring $(N=6.3)$. The expected heterozygosity $(\mathrm{He})$ in the parent generation and the total offspring was 0.72 and 0.61 , respectively. For all 14 loci, 23/97 alleles (23\%) that were present in the parents but did not appear in the offspring, while $13 / 89$ alleles (14\%) occurred in the offspring but were not found in the parents. The loci WPMS14 and WPMS18 showed a large positive estimate of null allele frequency (relative to other loci in the analysis) (Tab. III) and could therefore potentially involve the presence of a null allele [21]. It was possible to confirm the presence of a null allele for locus WPMS18 and the progeny harvested on N04; 12 seedlings appeared to be homozygous $213 \mathrm{bp} / 213 \mathrm{bp}$ while the mother N04 had genotype $223 \mathrm{bp} / 223 \mathrm{bp}$. The loci 
Table III. Parameters of genetic diversity for the adult $P$. nigra trees and the total progeny of the four mother trees for each SSR locus analysed. Expected heterozygosity (He), number of amplified alleles $(\mathrm{N})$ and null allele frequency estimate (negative values imply an excess of observed heterozygote genotypes).

\begin{tabular}{|c|c|c|c|c|c|}
\hline \multirow{2}{*}{ Locus } & \multicolumn{2}{|c|}{ Adults } & \multicolumn{2}{|c|}{ Progeny } & \multirow{2}{*}{$\begin{array}{c}\text { Null allele } \\
\text { frequency estimate }\end{array}$} \\
\hline & $\mathrm{He}$ & $N$ & $\mathrm{He}$ & $N$ & \\
\hline PMGC14 & 0.76 & 6 & 0.71 & 6 & -0.2241 \\
\hline WPMS03 & 0.86 & 7 & 0.79 & 7 & -0.0895 \\
\hline WPMS04 & 0.81 & 8 & 0.68 & 8 & -0.0238 \\
\hline WPMS05 & 0.72 & 7 & 0.69 & 7 & -0.0745 \\
\hline WPMS09 & 0.89 & 11 & 0.80 & 9 & -0.1032 \\
\hline WPMS10 & 0.89 & 11 & 0.79 & 8 & -0.0809 \\
\hline WPMS12 & 0.67 & 7 & 0.64 & 7 & -0.0674 \\
\hline WPMS13 & 0.83 & 9 & 0.75 & 9 & -0.0555 \\
\hline WPMS14 & 0.70 & 6 & 0.47 & 5 & 0.2241 \\
\hline WPMS15 & 0.28 & 4 & 0.045 & 5 & -0.0043 \\
\hline WPMS16 & 0.64 & 4 & 0.59 & 4 & -0.0336 \\
\hline WPMS 18 & 0.62 & 4 & 0.51 & 4 & 0.2840 \\
\hline WPMS19 & 0.76 & 8 & 0.60 & 6 & -0.0762 \\
\hline WPMS20 & 0.63 & 5 & 0.48 & 4 & -0.0852 \\
\hline
\end{tabular}

WPMS14 and WPMS18 were therefore eliminated for further paternity analysis. Successive amplification of a seedling of mother tree N01a at locus WPMS04 revealed that the heterozygous seedling mismatched for both alleles with the mother. This seedling showed the genotype $251 \mathrm{bp} / 271 \mathrm{bp}$ for locus WPMS04 while its female parent had the heterozygous genotype $249 \mathrm{bp} / 269 \mathrm{bp}$. This could be due to a mutation or to mislabelling of the seedling.

Microsatellite analysis of the remaining 12 SSR loci revealed 11 distinct genotypes in the 16 P. nigra candidate fathers in the total poplar stand (Tab. IV) and three different genotypes (N01, N01', N04) in the mother trees investigated. Generally, the paternal genotypes differed by several alleles on several SSR loci. However, there were two exceptions: N01' differed from N01 by only one out of the 28 alleles (at locus WPMS03) while the male tree M091 also differed by only one out of 28 alleles (at locus WPMS14) from the multilocus genotype represented by 6 males (Tab. IV). This latter difference could be confirmed by a controlled cross performed in the greenhouse between $P$. nigra female "N01" and $P$. nigra male "M091" (results not shown). No duplicate genotypes were found among the progeny plants analysed.

Paternity was determined with $95 \%$ confidence for $133 / 155$ $(86 \%)$ seedlings. When using a more relaxed confidence level of $80 \%$, paternity was assigned to $152 / 155$ or $98 \%$ of the seedlings. For $3(2 \%)$ seedlings, paternity was unresolved at the $80 \%$ confidence level. Six of the 11 candidate male genets (based on 12 SSR loci) of P. nigra in the poplar stands, contributed to the paternity of the offspring (Tab. IV). A highly significant difference was found between the observed paternities and the expected paternities under random mating, taking into account the number of ramets of each genet in the stand
$(P=0, \chi$-square $=146.36, d f=10)$. No paternities were assigned to the male cultivar $P$. nigra cv. Italica located outside the stand.

\section{DISCUSSION}

\subsection{Interspecific matings}

Two studies report on natural mating of $P$. nigra females in artificial stands which are surrounded by a range of compatible Populus species, including male trees of $P . \times$ canadensis $[22,26]$. In these observational studies and in common with former studies conducted in natural populations, no evidence for introgression of genes of $P$. deltoides was found in the offspring of $P$. nigra females. However, in all these studies the relative proportion of $P . \times$ canadensis males in or surrounding the study area was low $[2,7,9,13,22,26]$. It is suggested that, besides the hypothesis of pollen competition, also the relatively low proportion of interspecific pollen in the total pollen cloud could have been one possible reason for the lack of $P$. deltoides parentage detected in $\mathrm{OP}$ progenies of the $P$. nigra clones $[22,26]$. In this study, flowering $P . \times$ canadensis males (14) were present in the same abundance as $P$. nigra males (14) at the study site and asynchronous flowering was not a factor in preventing hybridisation between $P$. nigra and $P . \times$ canadensis $[28,29]$. When considering the poplar plantation as a whole, the area covered by $P . \times$ canadensis $(0.80$ ha) was about double that occupied by $P$. nigra ( 0.44 ha). Moreover, the poplar plantation was located in an agricultural landscape in which there were many other hybrid poplar plantations composed of $P . \times$ canadensis and $P . \times$ interamericana (cross between $P$. trichocarpa and $P$. deltoides). Despite the abundance of $P . \times$ canadensis hybrids, no evidence of introgression of genes of $P$. deltoides in the offspring of P. nigra was detected. Therefore, the results of this study suggest that under these field conditions pollen of $P$. nigra may be more successful than that from $P . \times$ canadensis in pollinating female black poplar. However, in a previous study it was shown that when native black poplar stands become very small compared to the abundant hybrid poplar plantations, gene flow from cultivated poplar into native black poplar can occur and the black poplar populations may therefore be in danger of being lost through genetic assimilation [30]. In the latter case, efforts should focus on maintaining and expanding the remaining non-hybrid native populations. Reforestation programmes combined with habitat restoration may limit the potential risk of gene flow with cultivated hybrid $P . \times$ canadensis poplars.

While our observations in this artificial poplar stand add to our understanding of the reasons behind the low levels of introgression found in natural black poplar populations, the results of this study leave several questions unanswered. Male reproductive success may be influenced by numerous factors such as the spatial distance to the mother tree, wind direction and velocity, stand density and canopy configuration. Individual male fecundity differences like size of the individual pollen load, pollen viability and duration of pollen release were not 
Table IV. For each candidate male tree (CM) of P. nigra in the study stand, the diameter at breast height (DBH) and the distance to the mother trees is given. For each male P. nigra genet in the stand, the frequency in the stand (F), the assigned paternities per mother tree (CERVUS, 95\% C. L.), the expected paternity frequency (P. exp.) under random mating and the observed paternity frequency (P. obs.) are given.

\begin{tabular}{|c|c|c|c|c|c|c|c|c|c|c|c|c|c|c|}
\hline \multirow[t]{3}{*}{$\mathrm{CM}$} & \multirow[t]{3}{*}{$\mathrm{F}$} & \multirow{3}{*}{$\begin{array}{l}\text { DBH } \\
(\mathrm{cm})\end{array}$} & \multicolumn{4}{|c|}{ Distance to mother tree $(\mathrm{m})$} & \multicolumn{6}{|c|}{ Assigned paternities (95\% C.L.) } & \multirow[t]{3}{*}{ P. exp. } & \multirow[t]{3}{*}{ P. obs. } \\
\hline & & & N01a & N01b & N04 & N01' & N01a & N01a & N01b & N04 & N01' & Total & & \\
\hline & & & & & & & 1999 & 2000 & & & & & & \\
\hline M029 & \multirow{6}{*}{6} & 72 & 24 & 8 & 54 & 7.5 & \multirow{6}{*}{15} & \multirow{6}{*}{30} & \multirow{6}{*}{22} & \multirow{6}{*}{35} & \multirow{6}{*}{13} & \multirow{6}{*}{115} & \multirow{6}{*}{0.375} & \multirow{6}{*}{0.864} \\
\hline M060 & & 74 & 13 & 28 & 19 & 44 & & & & & & & & \\
\hline M063 & & 81 & 16 & 31 & 15 & 47 & & & & & & & & \\
\hline M083 & & 51 & 37 & 52 & 8 & 69 & & & & & & & & \\
\hline M094 & & 79 & 53 & 68 & 22 & 85 & & & & & & & & \\
\hline M091 & & 70 & 52 & 67 & 19 & 84 & & & & & & & & \\
\hline M081 & 1 & 31 & 38 & 52 & 12 & 69 & 1 & 0 & 0 & 0 & 1 & 2 & 0.062 & 0.015 \\
\hline M086 & 1 & 82 & 45 & 59 & 14 & 76 & 8 & 0 & 0 & 0 & 2 & 10 & 0.062 & 0.075 \\
\hline M101 & 1 & 45 & 61 & 76 & 29 & 93 & 0 & 0 & 1 & 0 & 2 & 3 & 0.062 & 0.022 \\
\hline M102 & 1 & 43 & 176 & 191 & 152 & 205 & 0 & 0 & 0 & 0 & 0 & 0 & 0.062 & 0.000 \\
\hline M103 & 1 & 51 & 169 & 183 & 144 & 200 & 0 & 0 & 0 & 0 & 2 & 2 & 0.062 & 0.015 \\
\hline M114 & 1 & 76 & 74 & 89 & 43 & 105 & 1 & 0 & 0 & 0 & 0 & 1 & 0.062 & 0.007 \\
\hline M116 & 1 & 62 & 74 & 89 & 43 & 106 & 0 & 0 & 0 & 0 & 0 & 0 & 0.062 & 0.000 \\
\hline M123 & 1 & 60 & 79 & 94 & 48 & 111 & 0 & 0 & 0 & 0 & 0 & 0 & 0.062 & 0.000 \\
\hline M134 & 1 & 34 & 88 & 103 & 57 & 120 & 0 & 0 & 0 & 0 & 0 & 0 & 0.062 & 0.000 \\
\hline M139 & 1 & 29 & 94 & 109 & 65 & 126 & 0 & 0 & 0 & 0 & 0 & 0 & 0.062 & 0.000 \\
\hline
\end{tabular}

studied. $[23,26,31]$. The fact that the black poplar males compared to those of the $P . \times$ canadensis were closer and in a better position in terms of wind direction in relation to the females investigated, may also explain why the $P . \times$ canadensis males did not contribute to the seedling crops analysed. In order to test the hypothesis of inter-specific pollen competition under field conditions larger studies need to be conducted over several years in a range of environments in which more mother trees are sampled.

\subsection{Intra-specific matings}

In this study, we twice found two genotypes that differed only for one out of 28 alleles. Continuous human mediated vegetative propagation has probably extended the natural lifetime of many P. nigra genotypes in Belgium. For the heterozygous genotypes of N01 and N01' at WPMS03, it is therefore plausible to suggest that once a single somatic mutation has occurred at locus WPMS03 in a meristem which produced a shoot that was selected for further vegetative propagation. Although further research is needed to investigate the origin of these small genotypic differences, the results of this study confirm that it is important for parentage assignments based on large datasets, to take into account the possible existence of undetectable alleles, scoring errors and mutations [15, 20,21].

Mating patterns in a stand influence the levels of inbreeding, effective population size and the degree of genetic substructuring resulting from selection or drift [1]. Knowledge of mating patterns in seed orchards is also of value to plant breeders concerned with promoting cross-fertilization among cultivars or assessing the validity of OP progenies for use in genetic testing. The results of this study suggest non-random mating within P. nigra (Tab. IV) and indicate that female trees mate with a restricted number of males. The majority of the paternities $(115 / 133$ or $86 \%)$ were assigned to the genet represented by six ramets and 5 potential fathers did not contribute to the offspring (Tab. IV). For 3 seedlings ( $2 \%$ ) paternity was unresolved at the $80 \%$ confidence level. This is likely to be due to the fact that these seedlings and multiple equally-likely fathers share very common alleles at each locus which occur very frequently in the plantation. However, although the majority of the paternities were resolved, we cannot completely rule out that there may be gene flow from outside the study stand. The programme CERVUS provides no mechanism for estimating gene flow from outside the sampled population; no distinction is made between multiple, equally-likely fathers and no fathers within the sampled population.

The six ramets representing the genet that contributed to the majority of the paternities were generally trees with a well developed canopy relative to the other candidate fathers. Unfortunately, due to the clonal constitution of the study stand where several trees represented the same genet, we were not able to analyze relationships between distance to the mother trees and DBH versus paternity. $P$. nigra cv. Italica did not father any of the 155 seedlings investigated. Trees of $P$. nigra cv. Italica were located outside the stand at a distance of about $500 \mathrm{~m}$. This distance to the mother trees, combined with the early flowering phenology [29] might explain why this cultivar did not father any of the seedlings. These results agree with the findings of Tabbener and Cottrell [26] that there was asynchronous flowering and no evidence of mating between a female $P$. nigra and a male $P$. nigra cv. Italica growing about 
$350 \mathrm{~m}$ apart in Scotland. However, flowering of $P$. nigra cv. Italica may be more synchronous with wild black poplar resources in more Southern European regions such as France (Villar, pers. communication).

A small reduction in expected heterozygosity $(\mathrm{He})$ in the offspring compared to that in the parent population was observed and 23 alleles detected in the parents were not found in the offspring. Also, 13 alleles in the offspring were not found in the parents. The frequency of these latter alleles was usually very low and generally observed only once in the total progeny. Although amplification errors, scoring errors and mutations could partly explain the presence of these unique alleles of the progeny population, we cannot exclude gene flow from outside the study stand as a possible reason for the presence of these alleles in the offspring.

It is important for restoration projects of black poplar populations to take into account that the number of trees that effectively contributed to the offspring (i.e. effective population size) is likely to be smaller than the number of trees present in a restored population. Therefore, measures should be taken to maximise the effective population size in order to reduce genetic drift, inbreeding and subsequent reduction in diversity. The results of this study also indicate that half-sib progenies from seed orchards might not be a good source of reproductive material for restoration projects of black poplar populations because their genetic relatedness due to the effect of preferential mating.

Acknowledgements: This study has been carried out with financial support from the Commission of the European Communities, Agriculture and Fisheries (FAIR) specific RTS programme, PL-97-3386, "Genetic diversity in river populations of European Black Poplar for evaluation of biodiversity, conservation strategies, nature development and genetic improvement". It does not necessarily reflect its views and in no way anticipates the Commission's future policy in this area. The authors thank two anonymous reviewers for their comments on a previous version of the manuscript, Boudewijn Michiels for co-ordinating the greenhouse activities, David Halfmaerten, An Van Breusegem, Leen Verschaeve and Michaël Vandenhove for their skillful laboratory assistance.

\section{REFERENCES}

[1] Adams W.T., Griffin A.R., Moran G.F., Using paternity analysis to measure effective pollen dispersal in plant populations, Am. Nat. 140 (1992) 762-780.

[2] Benetka V., Mottl J., Vacková K., Pospísková M., Dubský M. Estimation of the introgression level in Populus nigra L. populations by means of isozyme gene markers, Silvae Genet. 48 (1999) $218-223$.

[3] Benetka V., Vacková K., Bartáková I., Popísková M., Rasl M., Introgression in black poplar (Populus nigra L. ssp. P. nigra) and its transmission, J. For. Sci. 48 (2002) 115-120.

[4] Cagelli L., Lefèvre F., The conservation of Populus nigra L. and gene flow with cultivated poplars in Europe, For. Genet. 2 (1995) 135-144.

[5] Cervera M.-T., Storme V., Ivens B., Gusmao J., Liu Ben H., Hostyn V., Van Slycken J., Van Montagu M., Boerjan W., Dense genetic linkage maps of three Populus species (Populus deltoides, P. nigra and $P$. trichocarpa) based on AFLP and microsatellite markers, Genetics 158 (2001) 787-809.
[6] Fady B., Hochu I., Polymorphisme enzymatique sur gel d'amidon de quelques espèces forestières méditerranéennes : protocoles expérimentaux [Isozyme polymorphism of Mediterranean forest tree species based on starch electrophoresis: experimental methods], INRA publication URFM-Gen/98.01, Avignon INRA, 1998, pp. 22.

[7] Fossati T., Grassi F., Sala F., Castiglione S., Molecular analysis of natural populations of Populus nigra L. intermingled with cultivated hybrids, Mol. Ecol. 12 (2003) 2033-2043.

[8] Gering L.R., The relationship of diameter at breast height and crown diameter for four species groups in Hardin County, Tennessee, South. J. Appl. For. 19 (1995) 177-181.

[9] Heinze B., A PCR Marker for a Populus deltoides allele and its use in studying introgression with native European Populus nigra, Belg. J. Bot. 129 (1997) 123-130.

[10] Heinze B., Biochemical and molecular genetic methods available for the characterization of Populus nigra L., in: Turok J., Lefèvre F., de Vries S., Alba N., Heinze B. (Eds.), Populus nigra Network Report of the fourth meeting, 3-5 October 1997, Geraardsbergen, Belgium, IPGRI Rome, 1998, pp. 42-61.

[11] Heinze B., PCR-Based chloroplast DNA assays for the identification of native Populus nigra and introduced poplar hybrids in Europe, For. Genet. 5 (1998) 31-38

[12] Houtzagers G., Het geslacht Populus in verband met zijn betekenis voor de houtteelt, Wageningen, Nederland, H. Veenman and Zonen, 1937.

[13] Janssen A., Unterscheidung der beiden Schwarzpappelarten Populus nigra L. und $P$. deltoides Marsh. sowie ihrer Arthybride $P$. $\times$ euramericana (Dode) Guinier met Hilfe von Isoenzymmustern, Holzzucht 51 (1997) 17-23.

[14] Janssen A., Artbestimmung von Schwarzpappeln (Populus nigra L.) mit Hilfe von Isoenzymmustern und Überprüfung der Methode an Altbäumen, Absaaten von kontrollierten Kreuzungen und freien Abblüten sowie Naturverjüngungen (Species determination of Black poplar (Populus nigra L.) based on isozymes and isozyme analysis of black poplar trees, half-sib offsprings and full sib progenies originating from controlled crosses), in: Weisgerber $\mathrm{H}$. Janssen A. (Eds.), Die Schwarzpappel, Hessischen Landesanstalt für Forsteinrichtung, Waldforschung und Waldökologie, 1998, pp. $32-42$.

[15] Jones A.G., Ardren W.R., Methods of parentage analysis in natural populations, Mol. Ecol. 12 (2003) 2511-2523.

[16] Kajba D., Romanic B., Morphological leaf variability of the European black poplar (Populus nigra L.) in natural populations in the Drava River Basin in Croatia, in: Van Dam B.C., Bordács S. (Eds.), Genetic diversity in river populations of European black poplar - Implications for riparian eco-system management, Proceedings of an international symposium held in Szeksárd, Hungary from 16-25 May 2001, Csiszár Nyomda Ltd., Budapest, 2002, pp. 221-228.

[17] Khasa D.P., Nadeem S., Thomas B., Robertson A., Bousquet J. Application of SSR markers for parentage analysis of Populus clones, For. Genet. 10 (2003) 273-281.

[18] Lefèvre F., Kajba D., Heinze B., Rotach P., de Vries S.M.G., Turok J., Black poplar: A model for gene resource conservation in forest ecosystems, For. Chron. 77 (2001) 239-244.

[19] Marshall D.L., Avritt J.J., Shaner M., Saunders R.L., Effects of pollen load size and composition on pollen donor performance in wild radish, Raphanus sativus (Brassicaceae), Am. J. Bot. 87 (2000) 1619-1627.

[20] Marshall T.C., Slate J., Kruuk L.E.B., Pemberton J.M., Statistical confidence for likelihood-based paternity inference in natural populations, Mol. Ecol. 7 (1998) 639-655

[21] Pemberton J.M., Slate J., Bancroft D.R., Barrett J.A. Nonamplifying alleles at microsatellite loci: a caution for parentage and population studies, Mol. Ecol. 4 (1995) 249-252. 
[22] Rajora O.P., Mating systems and fertilizing pollen gene pools of Populus deltoides Marsh. and P. nigra L. clones located in different compatible species neighbourhoods as inferred from isozyme analysis, in: Proceedings of the 20th Canadian Tree Improvement Association, part 2, Canadian Forest Service, Ottawa, 1986, pp. 134-141.

[23] Rajora O.P., Genetic structure and identification of Populus deltoides Marsh. clones based on allozymes, Genome 32 (1989) 440448

[24] Rajora O.P., Dancik B.P., Allozyme variation and inheritance in leaves of Populus deltoides, $P$. nigra, P. maximowiczii and $P . \times$ canadensis in comparison to those in root tips, Silvae Genet. 41 (1992) 289-292.

[25] Smulders M.J.M., van der Schoot J., Arens P., Vosman B., Trinucleotide repeat microsatellite markers for black poplar (Populus nigra L.), Mol. Ecol. Notes 1 (2001) 188-190.

[26] Tabbener H.E., Cottrell J.E., The use of microsatellite markers to study paternity in seedlings produced by a range of poplar species, For. Ecol. Manage. 179 (2003) 363-376.
[27] Van der Schoot J., Pospísková M., Vosman B., Development and characterization of microsatellite markers in black poplar (Populus nigra L.), Theor. Appl. Genet. 101 (2000) 317-322.

[28] Vanden Broeck A., Potential gene flow between native European black poplar (Populus nigra L.) and cultivated poplars in Belgium, Ph.D. thesis, University Ghent, Ghent, 2004.

[29] Vanden Broeck A., Cox K., Quataert P., Van Bockstaele E., Van Slycken J., Flowering phenology of Populus nigra L., P. nigra cv. Italica and $P . \times$ canadensis Moench. and the potential for natural hybridisation in Belgium, Silvae Genet. 52 (2003) 280-283.

[30] Vanden Broeck A., Storme V., Cottrell J.E., Boerjan W., Van Bockstaele E., Quataert P., Van Slycken J., Gene flow between cultivated poplars and native black poplar (Populus nigra L.): A case study along the river Meuse on the Dutch-Belgian border, For. Ecol. Manage. 197 (2004) 307-310.

[31] Vanden Broeck A., Quataert P., Rodán-Ruiz I., Van Bockstaele E., Van Slycken J., Pollen competition in P. nigra females revealed by microsatellite markers, For. Genet. 10 (2003) 219-227. 